\title{
Typology of Metavisioner Headmaster of Islamic School Leadership Based on Sunnah of Prophet Muhammad
}

\author{
Nadhirin; Mursid Saleh; Achmad Slamet; Sugiyo
}

\begin{abstract}
This study aims to identify and analyze (1) the integrity and personality of the leadership of headmaster (2) the leadership of headmaster in formulating and communicating the vision and mission of Islamic school (3) the leadership of headmaster in establishing communication with stakeholders and (4) the leadership of headmaster in building culture of academic quality and (5) to find a typology of leadership of headmaster.This study used a qualitative approach with phenomenological paradigm post-posivistic with case study design (case study). Data collection techniques in this study were to (1) Observation (2) interviews and (3) documentation. Mechanical testing the validity of the data include triangulation techniques. Data were analyzed using interactive cycle model analysis techniques that included (1) collecting the data (2) reduction of data and (3) the data display.It was found that the leadership of NU Banat Kudus headmaster preferred character and morality as a first leader and foremost requirement is embodied in the profile of clerics. Islamic school of Aliyah vision oriented to personal achievements ideal grounded in piety and morals for the purpose afterlife world destinations through the mastery of science and technology. Communication built by headmaster with all elements of the stakeholders to follow the pattern of communication in Pesantren, which put clerics or religious leaders as a central figure. Academic quality was controlled through the quality control unit. Quality built and achieved by the headmaster oriented on study of religious knowledge and mastery of the Arabic language and the mastery of science. Typology headmaster leadership was leadership metavisioner based sunnah of the Prophet Muhammad set Pesantren.
\end{abstract}

Keywords: Leadership, Principals, Metavisioner, the Sunnah of the Prophet Muhammad

\section{Introduction}

Management education is an activity that is planned and programmed to utilize and empower all educational resources for the realization of quality education services, effective, efficient and accountable. Quality education and respond to the needs and demands of time needed professional management. All stakeholders (stakeholders) that are the school, community and government work together for the sake embodied the ideals of education. Regulation of the minister of education number 19 of 2007 states that the management of primary and secondary education requires 6 standard management, namely (1) planning program (2) the implementation of the work plan (3) monitoring and evaluation (4) school leadership or Islamic school (5) management information system and (6) a special assessment. One of the strategic management standard that requires continuous innovation in accordance with the changing dynamics of leadership. Based on Government Regulation No. 19 of year 2005 which was renewed in the PP number 32 year 2013 confirms that the organization of education in Indonesia must meet national standards of quality for the sake of accountability. National education standards are the minimum criteria that must be met in organizing educational activities throughout Indonesia. With the national education standards, then the entire formal education institutions, including Islamic school education institutions should be able to adjust to other formal education institutions under the coordination of the Ministry of Primary and Secondary Education.

Islamic school is characterized by a formal educational institution that organizes religious education services for the wider community. Society needs the existence and continuous of educational activities at the Islamic school. The basic aim of education in Islamic school convening for the community is to provide public education and religious services for the community. Making quality Islamic school is shared responsibility between government, community and education providers. All interested parties are united and work together for mutual support the realization of the ideals of the Islamic school, which is to realize universal education, healthy inner and outer, spiritual and body, gethappiness and Hereafter. Law on National Education System No. 20 of 2003 to give equal attention to all the institutions of education providers, including Islamic school education. Islamic schoolwith all the weaknesses and strengths have historicity and cultural significance for the community. Good organization is organization which has good leadership and proper. Good management without the support of the right leadership will make the people who work in organizations such as passive, routine, mechanistic components and will create boredom for people working in the organization. Moreover, the position and function of leadership in educational institutions, the leadership has a very important role and strategic. 
Ideally, advanced educational institutions in addition having a professional management is needed approach and appropriate leadership model. FormalIslamic school is the educational institutions which has relatively typical character of organizational and leadership characteristic formed by the historical and cultural value system that forms the Islamic school. Nevertheless, as an institution of formal education, Islamic school management processes are managed in accordance with standard procedures and the school in general. Leadership has a very strong influence on the performance of the organization so it is rational when adversity education one of them caused the leadership performance that cannot adapt to change and are also unable to create educational strategies that are adaptive to change. inKudus Central Java Indonesia there is one Islamic senior high schools. It is the largest Islamic school specifically for daughter learners (Banat) in the kudus City and its surroundings. The organization's reputation is quite good. Community gives confidence to these institutions to educate their daughters. MA NU Banat culturally this is aIslamic school standing and great because especially the role of the Kyai and religious leaders in kudus. Kyai's leadership in this Islamic school tend to be more dominant in comparison with formal leadership in the school in general. One of the characters is that the authority of the leadership of religious scholars and decision makers are in Kyai. There is some uniqueness in leadership regeneration, because these institutions rarely have to wait for a leadership change real leaders (ulama Islamic school) experienced udzur (snag do the job) may be for reasons of age or health. MA NU Banat is a formal educational institution that Islamic religious character that makes Muhammad as (the good model) or (uswah hasanah) _ a good example. Although MA NU Banat is patterned religious institutions, boarding background but this institution has obtained ISO 9001: 2008, as an expression of the fulfillment of the standards of quality management of the institution.

Form the phenomenon of the delivery of education in Islamic school, the writer wanted to do research on leadership headmaster source values that underlie leadership to realize the quality, competitive, adaptiveIslamic school, and able to bring humans a strong future that is able to build a world order that is humane, dignified and civilized.The focus of this research is the leadership of the Islamic senior high schools based on the Sunnah of Prophet Muhammad (Sunnah of Prophet Muhammad SAW). The focus can be formulated from the following questions: (1) How is the headmaster of integrity and leadership personality? (2) How does headmaster formulate the vision and mission of Islamic school? (3) How does the leadership of headmaster establish communication with stakeholders of Islamic school? (4) How does the leadership of headmaster develop a culture of academic quality in Islamic school and (5) how the typology of leadership headmaster?

\section{Research Methods}

The approach in this study is qualitative phenomology approach. Subject in this study is the head of the Islamic school. Among the leaders of the three Islamic school are the heads of Islamic schools by researchers such persons referred to as key informants (key informants), while teachers, community leaders, parents, and alumnusIslamic school researchers refer to as informants supporters. Data collection techniques in this study using observation, interview and documentation. Mechanical test the validity of this research is by triangulation (croos or confirming) research data obtained from observation, documentation technique with data obtained by interview, so that the collected data is valid or invalid to the next can be analyzed to obtain research findings. Data analysis technique used is interactive cycles as proposed by Milles and Huberman (1992), quoted by Sugiyono (2008: 337) that the analysis conducted during the study process is done through a series of processes, data collection, reduction, presentation and verification of data. The location of this research in the Islamic senior high schools MANU Banat Kudus, Central Java, Indonesia

\section{Research findings}

\section{Research Findings And Discussion}

\section{Integrity and personality of the leader of the Islamic school}

Integrity and personality of leaders include (1) Capability of Chief Islamic school be uswah hasanah for all citizens of Islamic school (2) Be consistent, hard work and resignation (resignation on the results of a job at the start, proceed and finish a job) (3) Istiqomah in keeping the spiritual life (4) personality mannered and tawadhu 'keapada everyone (5) responsible for the tasks assigned (6) hard against corruption

\section{Visionand mission ofIslamic school}

Headmaster leadership in formulating and realizing the vision of madrasas include (1) formulating the vision and mission of the Islamic school. Vision of MA NU Banat Islamic schoolwas the realization of Islamic school daughter as a center of excellence that is able to prepare and develop qualified human resources in the field of IMTAQ and science and technology that Islamy and Sunny and the mission of this Islamic school is organized educational beroreintasi quality, both in academic, moral and social so as to prepare and develop quality human resources in the field of IMTAQ and science and technology in order to realize baldatun 
Thoyyibatun Warobun Ghofur (2) promoting the vision, mission, goals and programs Islamic school (3) Islamic school vision is formulated based on the needs and demands of future changes in (4) visions Islamic school contains ideals high ideals and oriented towards the implementation of the social system order beradasarkan baldatun concept Thoyyibatun Warobun Ghofur (5) based on the vision Islamic school principal values upheld by Islamic school (6) Islamic school vision guided by spiritual values.

\section{Communication with Islamic school stakeholders}

Leadership headmaster with all elements of stakeholders includes (1) the taboo cultural to talk about positions (2) firmly in giving sanctions to violating the law by indiscriminately (3) discipline in the time and work (4) coordination (silaturrahim) through traditional structured meeting (5) promoting spiritual capital and social capital to the financial capital and human capital (6) the approach of humanity according to the Islamic school culture in supervision activities for the purpose of professionalism (7) invite all teachers and employees not to discuss salaries and income (8) build cooperation with the community and parents and guardians of students (9) build relationships with alumnus.

\section{Building a culture of academic quality}

Leadership headmaster in building a culture of academic quality is to (1) a commitment to the quality of the best services (2) create a culture of love in education in Islamic school (3) provide educational facilities and infrastructure Islamic school adequate and create an environment Islamic school safe and orderly (4) implement basic principles and values of the organization (5) forming WMM (Deputy quality Management) as an institution of structural quality control of Islamic school (6) to make policy and quality objectives (7) has a program seed (8) targeting institutions air-ISO (9) targeting accreditation with scores high.

\section{Integrity and personality of a leader}

\section{Discussion}

From the data on the exposure of headmaster leadership efforts in building integrity and leadership personality cross Islamic school, raises questions as follows:

(1) Why must headmaster have integrity and a good personality?

The leader is a best personality in the community. Islamic school is characterized by a religious institution. How Islamic schoolinstitutions every day educate students to personality and good moral behavior but the boss is not no or less have a good moral integrity. Awakening morality is influenced by students' moral integrity leaders and teachers who teach. One of the attitudes that shape integrity and good morality is to have an attitude of humility (not inferior) and not to be arrogant in its various forms. as Prophet Muhammad asserts that:

من تواضع رفعه الله ومن تكبر وضعه الله That is: who the people are willing to humble themselves (not arrogant and does not umuk) then Allah will raise position dan give him honor. But otherwise the person who takabbur (arrogant, stubborn and conceited), then God just humiliate it (in front of others).

Prophet Muhammad has affirmed that:

Meaning: that honor a man was there because of the knowledge and behavior.

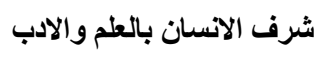

(2) Why should headmaster have personally liable?

Narrated by Imam Muslim, the Prophet Muhammad said:

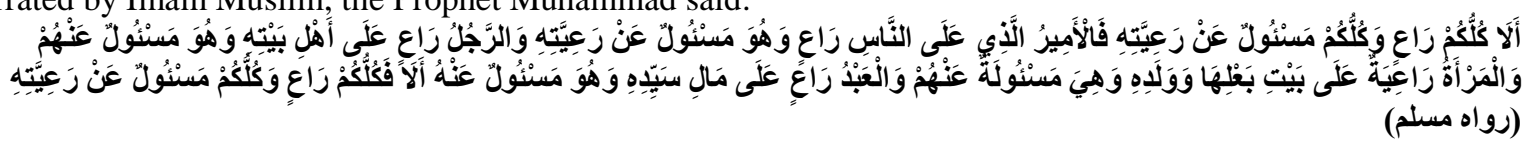

That is the truth, each of you is a leader and each of you is responsible for his leadership. The head of government is the leader and her responsibilities. her husband is the leader and no responsibility for the lives of his family members. Wife is a leader and has the responsibility for children and devoted to her husband and keeping mandate. Maid is a leader and is responsible for the employer's property. And you remember, that in fact each one of you is a leader and therefore imposed the task and responsibility. (Nafi '2006: 352) Responsibility is the key competencies of a leader.Because the responsibility is the consequence of the mandate and the authority that has been given by the institution to him. Responsibility headmaster leadership basedsunnah of prophet Muhammad have the consequence of a very extensive and demanding personal plenary leader. Islamic school education institutions not only form the beings who master science and technology but also print out a pious sholehah persons, noble character and obedience to their religion. When institutions are facing a difficulty then head Islamic school the first time and stood in front to lead his anah in solving all the problems that exist and prevent it. If there is a disgrace that befell his men, then head of Islamic school is the first person in charge and with a great soul says that disgrace that befell his men was solely because of his leadership. If there is good and achievement for the institution, then based leader sunnah of Prophet Muhammad bestows favor and that achievement to his subordinates. 
As the Prophet Muhammad said:

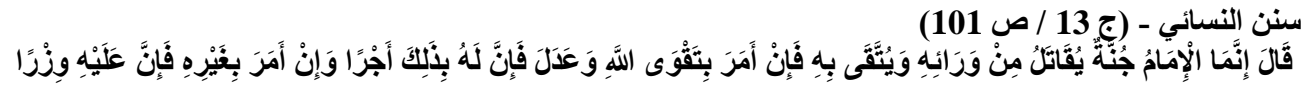

Meaning: The Prophet said: the real leaders are protective. People fight behind him and appealed to him. If he is ruled by faith and justice then his reward and if he ruled otherwise then it is sin (Nafi '2006: 101)

Also said by Ibn Majah in the book of hadist books, namely:

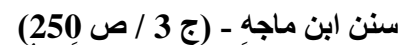

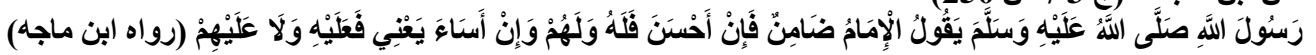
That is; The Prophet said: the leader is the responsible person, if he is good then he led him and for reward. And if it is bad then it is sin and not for the leads (Nafi '2006: 250)

(3) Why mustheadmaster have a spiritual quality constancy?

Understanding leadership in the Sunnah of the Prophet Muhammad is not only formal and purely administrative. Leadership in the Sunnah of the Prophet Muhammad is not only how to get someone to do a task in an organization. But leadership has implications far. Trasendental concept is the spirit of oath leader. Trasendental Leadership has the understanding that a leader must have the moral qualifications of spiritual good and brave deeds during the whole account led to God and should strive to create an order of life that led people to be better, more physically and mentally prosperous, fair and in God ridla.

(4) Why should headmaster have an open attitude and based on the principle of legality in his duties?

Leadership that is run by headmaster popularity is based on the principle of legality. Legality (oath) is the basis of a person carry out the mandate of leadership. In this context, oath (inauguration) actually has the same meaning as the appointment and the establishment of a person by an organization to perform organizational tasks. Leadership oathbasedSunnah of the Prophet Muhammad SAW has a very broad sense, inclusive, totality, and has a horizontal and vertical accountability, inner and outer pledge, vow carry out the mandate of tasks and obligations. In- leadership based sunnah of Prophet Muhammad laid function as a holy ceremony to someone who will undergo a noble duty of leadership. Oath also have implications far to the risk of eschatological (get torture or favors in life after death as a result of his leadership) on the measures taken during the lead institution. As the Prophet Muhammad said in the Muslim shohih book hadith narrated by Muslim Faith, namely:

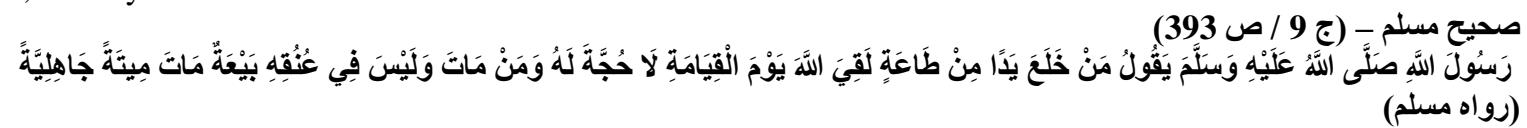

It means: Allah's Apostle said: whoever is removing his hand from obedience (disloyal) will meet God one day in the Day of Judgment without defense and whoever dies while his neck was no proof of loyalty, then he dies in a state jahiliyyah (Nafi '2006: 393)

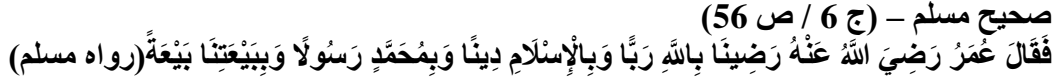
Meaning: Umar said (in the presence of the Prophet): We are willing to Allah as our Lord, Islam as our religion and our Prophet Muhammad prophet and we declare an oath of fidelity to the truth (Nafi 2006: 56).

Leadership Head createIslamic school in formulating vision and mission of Islamic school

(1) Why should headmaster formulate and understand the vision and mission?

Vision-oriented leadership is leadership that characterizes intelligent view of everything that will happen in the future. Education is the regeneration activities that are continuous and unbroken. Everything that happened in the past, the present and the future in education is seen as interconnectedness, intact and continuous. Curriculum provided at this time and indeed to meet the demands for 5-10 years to come. The curriculum is designed now is not to meet the demands and needs of the moment. Islamic school advanced demanding headmaster capable and smart in doing forecasting the future. The accuracy headmaster in reading potential changes and needs in the future, it takes complete data about what is happening now and the past as well as reading and analyzing the potential changes based on the law of cause and effect. Mulyadi (1998: 11) explains that there are two stages in the creation of the vision, namely (1) to trend watching, predict the likelihood-possibility that occur in the future through the expertise of headmaster in a field that was involved and the sensitivity to signals of nature and its amendments, and also have the power to draw closer to God as an extraordinary supernatural powers that can guide behavior in capturing the meaning of a natural phenomenon. (2) Doing envisioning, ie the ability of the leadership to formulate a vision based on the observation of a trend of change that will occur in the future. 
(2) Why should Islamic school vision be based on the core values of the organization and its formulation involving all stakeholders?

Islamic school had a key organizational values upheld by every individual in the Islamic school. The key values of Islamic school be basic principles for formulating a vision. All stakeholdersof Islamic school elements required to know the principles and values of primary Islamic school. Many Islamic schools education institutions, but each Islamic school has different characteristics and typology.Different characteristics of the organization isbecause of differences in value systems. According to Locke in Aan Komariah and CEPI Triana (2005) specifies that the principles, guidelines and beliefs and values of the organization's core become guides and also as the basis for the mission of the institution in order to realize the vision. The key values that become the paradigm of the institution actually have a very strong role in controlling vision. System of values shared by an organization are very hidden, invisible if not deeply internalized. Institutions put the value as the basis for the agency to form ideal vision philosophy. The role of visionary leadership is to give an example or how strategically in implementing the vision. When observed, the argument about visionary leadership, the leadership model developed by Locke (1997: 10) almost in tune with his ideas as shown in the following picture:

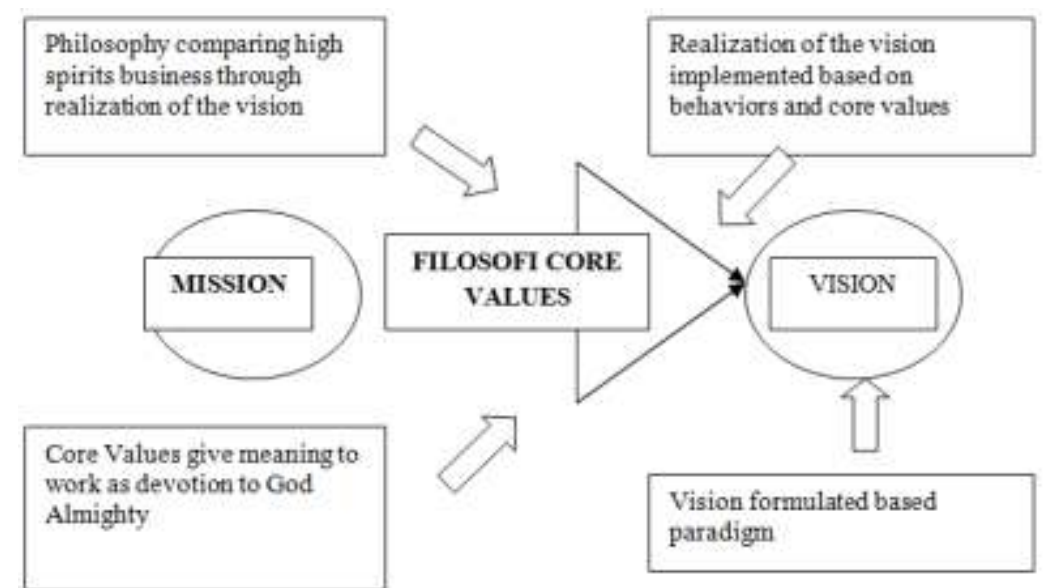

Pictures of the relationship between vision, mission, core values and core beliefes

(3) Why shouldheadmaster take the right decisions and prioritize institutional objectives rather than individual goals.

Theoretically, decision-making is a leadership activity to select and define the best path as a way out of the problems faced by the organization to achieve the desired objectives. Often there was a decision taken by a leader, not a solution of the problems faced by the institution, but rather with a decision of new more complicated problems. Leaders are required to truly understand the vision, mission and goals of the institution he leads, so that a decision taken always in accordance with a common goal and not the goal of the individual or group of people. As the statement of the Prophet Muhammad:

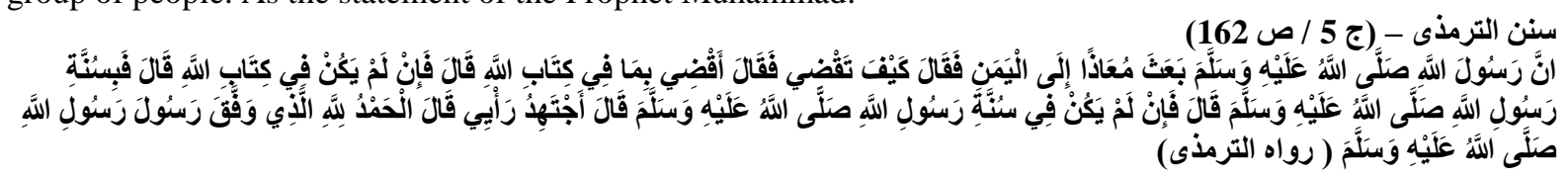

This means: Verily Allah sent Mu'ad to Yemen. He said how you'll decide? Mu'ad answer I will decide based on what is in the Book of Allah. The Prophet asked, how when not in Allah's Book? Mu'ad answer: with the Sunnah apostles. The Prophet asked again, if not in sunnah apostles, Mu'ad answered: I will examine with opinion. The Prophet said all praise be to Allah who has given guidance to the messenger of Allah (Nafi '2006: 162) In the Sunnah of the Prophet Muhammad SAW Mu'ad, companions of the Prophet Muhammad has undertaken the task of leadership in the decision of a problem encountered during the trip as well as in the country of Yemen. Prophet Muhammad provides a great tribute to his man who also is a friend (friend) who is able to decide on a case that is based on the principles and capabilities friend. Even Prophet Muhammad had never faced such cases. It is the very modern passage and democratic leadership on 15 centuries ago. The leadership style of the Prophet Muhammad without being apologists have proved that before the birth of modern leadership theory, the Prophet Muhammad has been practicing leadership that respects each individual's ability and give each individual the opportunity to make decisions.

In another hadith the Prophet Muhammad SAW said:

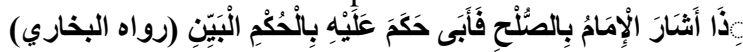


Meaning: If the leader instructed to make peace and they oppose those leaders must take a clear and unequivocal decision (Nafi '2006: 217) Leadership of Principals in Building Communication with Stakehoders of Islamic school There is some question why the headmaster had to establish communications with stakeholders, namely:

(1) Why mustheadmaster be a facilitator and mediator when there is a conflict or misunderstanding between stakeholders of Islamic school?

A leader in an educational institution would not be appropriate to put yourself in a group and clashed with other groups that are still in the institution. Conflicts of interest in an institution are still seen as something that is fair and is seen as a dynamic institution, as long as the conflict is not to cause disruption of order delivery of education. Interpersonal communication among teachers and employees do not get interrupted. Conflict within an organization is indeed a form of convergence is not the same understanding of a problem from a different angle. Misunderstanding between the parties stakeholders in educational institutions if not managed or addressed properly so would potentially interferedisintegration of organization. Differences in viewpoints in advancing the institution is amazing, even the difference it has become the law of nature, and in the context of the Sunnah of the Prophet Muhammad difference ummah is a mercy that became life is dynamic and full of color and rich repertoire of thoughts. Leaders must be able to take a stand in the middle and have to create justice for all men and men reconcile if strife or even conflict. As has been affirmed by the Prophet Muhammad is narrated by Iman Bukhari in the book of hadith, that is:

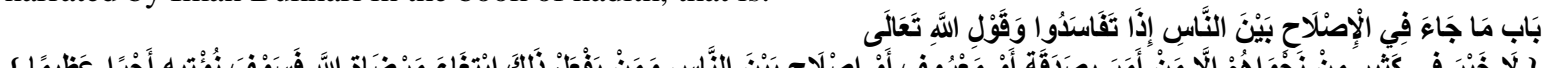

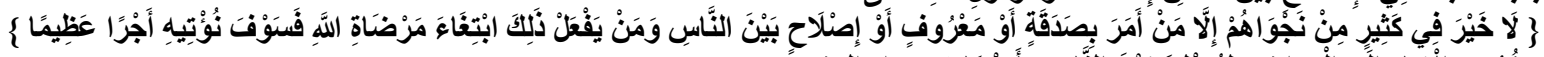

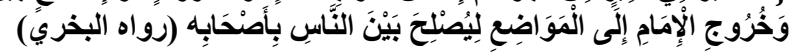

Meaning: A leader fell directly into the field to meet men and reconcile if among them there is a conflict (Nafi '2006: 190)

(2) Why shouldthe post of headmaster not be asked to without going through the procedures of credible and transparent?

In the reference-based leadership of the Prophet Muhammad, the leader is a sacred duty and noble task in undertaking the community that only special people who can carry out the task of leadership. The leader is the representative of God on earth that brings a huge task to care for and preserve the human life and nature to keep balance, harmony, full of beauty and away from conflict and war and bloodshed. Not contrary, leaders came to beating the drums of war between members of the organization. No people sign up to become a leader much less ambitious. The concept of leadership of the Prophet Muhammad did not know the buying of voters to elect people who had chosen to be the leader let alone to justify all the ways to be a leader. Leadership Prophet Muhammad did not know the kidnappers abduct, brawling and even murder for the sake of someone sitting in a chair position, but after the Prophet Muhammad. Being a leader is very heavy indeed, even the soul and the family should be ready sacrificed for the sake of people's lives for the better. But in reality many people who want and request to become a leader. The leader of the corrupt mentality one underlying cause is due to become a leader should ask for and buy at a great price.Requesting be a leader, issued a material capital, buying votes, was elected leader (served) then corruption is a package model of leadership that is very far from the leadership of the Prophet Muhammad. The selection mechanism to register themselves with certain requirements are still reasonable and proportional, therefore everything is technical and administrative aimed set order election who become candidates for the head. Candidates who deserve chief who later would lead an institution is left entirely to the people who will vote. In addition, any candidate not elected heads for not getting the most votes would not be appropriate to prop elected leaders. A people who vote for candidates who are not elected head should also be sincere (sportsmanship) and divert the full support of the elected leader. If necessary and anyone can be a leader election is based on the agreement if the community he leads is a bit like an educational institution. Therefore ask the leader be condemned by the leadership of the Prophet Muhammad as narrated by Imam Muslim in Saheeh Bukhari hadith book of Muslims, namely:

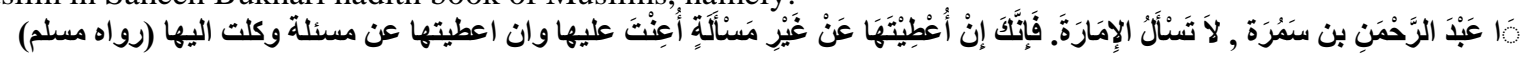

Meaning: Do not ask for positions, because if you were granted without asking then you will get help and if you were given for the request, then you will get into trouble (Nafi 2006: 453)

(3) Why does headmaster leadership in financial management Islamic school need to be accountable and transparent?

Leaders commitment arenot to commit acts of corruption and dividend simply meant as an act of selfenrichment and family in an illegal manner. Acts of corruption is only done by those who have power and authority to use the agency budget. Without power, one can not engage in corruption. Every public institution that organizes a public service there is always a financial management activities there, not least is the Islamic school education institutions. Potential misuse of public finances could happen in any institution. Leadership based on the Sunnah of the Prophet Muhammad strongly condemned acts of corruption. Corruption is a despicable act of a leader. Corruption can destroy the institutions in which corruption was working and even in a 
large scale can destroy joints life of the nation. Islamic school as an institution characterized by religion has an opportunity to contribute a role in improving the system of national life with one of them being held leadership Islamic school education that is based on the Sunnah of the Prophet Muhammad, that's a commitment not do unlawful acts, namely corruption. Property or other forms of wealth obtained by corruption is not brought blessed (no benefits). A simple indicator of wealth is a blessing not result in an unsettled life with accompanying problems of life that never no way out. It might happen in life now, later. It might happen to himself, the child offender, wife or even the closest people. Prophet Muhammad has been asserted in the book of hadith narrated by Ibnu Hiban below:

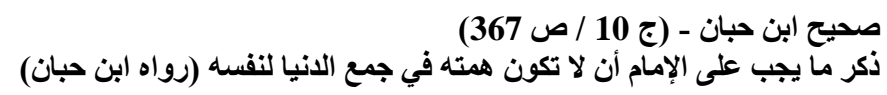

Meaning: Describes the obligation of a leader has no ambition to accumulate wealth to enrich themselves (Nafi '2006: 367).

It is also reported in other parts of ketidakmanfaatkan treasures collected by leader of corruption, namely:

Meaning: Describes the obligation of a leader not to take property unless properly to such property to be a blessing (Nafi '2006: 371). Narrated by Imam Bukhari about the simple lifestyle of a world leader like Prophet Muhammad and his companions Umar. They meet the needs of vehicle camels and personal needs and family of his own money and not the facilities or government agencies. This is indeed an ideal uswah leadership. Leadership Prophet Muhammad fight for the prosperity of the people and not vice versa, the leaders who seek wealth in the tengat suffering and misery as occurred during this time. Prophet Muhammad said:

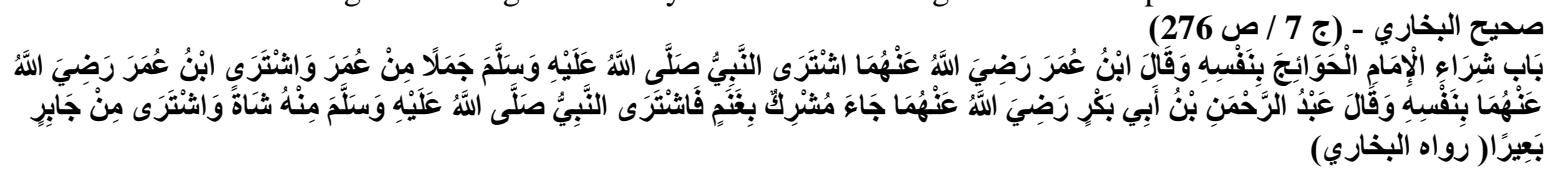

Meaning: A leader buy household needs with her own money and said r.a Umar that the Prophet Prophet Muhammad SAW bought a camel from Umar and Ibn Umar buy a camel for himself. Said Abdurrahman ibn Abi Bakr that come polytheist brought goats and purchased the Prophet, the Prophet also bought the camel from Jabir (Nafi '2006: 276) Other diseases that plague the leaders and authorities in all institutions of accepting bribes on a lavatory desired by certain parties in breach of the law and ethics. In the context of the provision of education, bribery (bribery) is usually done by a rogue parents so that children can be accepted at a particular school or for their child to graduate with high scores on a test moment. Prophet Muhammad asserts in the book of hadith narrated by Ibn Majah, as below.

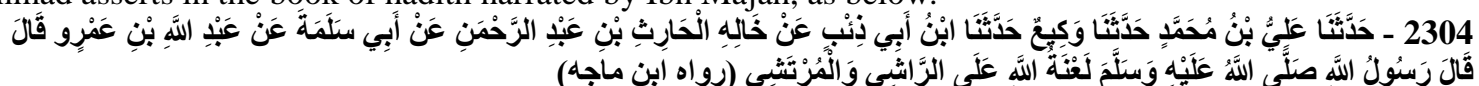

Meaning: Allah has cursed the briber and the recipient of a bribe (Nafi '2006: 101)

(4) Why shouldheadmaster be able to communicate to educators and education personnel?

Communicating is the exchange of thoughts and feelings to convey ideas and concepts. Headmaster demanded to have the art of communicating in accordance with the cultural background Islamic school. Teachers and education personnel require communication with the headmaster who is expected to listen to all the problems and hopes of his men. Organizations will be great with strong leadership. No exception Islamic school organization. Islamic school is characterized by formal education institutions to provide religious education to realize the vision of the ideal man, physically and spiritually healthy, master of science, able to build a life in the community and characterless Indonesiaan and oriented to obtain success in this world and hereafter. To realize the ideals of the foundation needed strong leadership. Leadership is built on the foundation of a strong personal leadership personality mature, intelligent in thinking, far into the future-oriented and able to spend yanag complex problems facing organizations. Therefore headmaster of an educational leader, as exemplified by the Prophet Muhmmad, are required to have a character of strong leadership, namely: (1) prioritizing function as a cornerstone in selecting people or something, not the appearance or external factors other (2) prioritize in terms of expediency rather than vanity (3) prioritize the more urgent than can be delayed (4) He was more concerned about others than himself (5) He chose the path that is most difficult for him and the easiest to its people and (6) He has put a priority hereafter purpose than mundane purposes (Ahmad Multazam, 2016) 
Principals Leadership in Building a Culture of Islamic Scshool Quality Academic

(1) Why shouldIslamic school provide facilities and infrastructure were comfortable learning for students?

Many factors are related to school quality learning outcomes. One of them is the fulfillment of learning facilities representative. So that the conduciveactivities it is necessary safe Islamic schoolenvironment of various social disturbances and natural disturbances. The physical environment is orderly, there are buildings and building according to its purpose, maintain cleanliness and arrangement of lush gardens, cool and beautiful will provide a psychological effect to all of those who were there atIslamic school for a longer and more serious in learning. Supposedly architecture school building construction and spatial distinguished by office buildings. The building where employees learn at the schools where children learn should be distinguished design. Now In large cities found many school buildings do not meet the requirements as a building that is destined for learning. The lack of residual soil for absorption, and also landscaping area and also a teacher and student mobility as well as citizens of other schools. Total land area schools are filled with a permanent building, the parking lot is narrow and congested will give negative impact on the mental and social development of students. Students and teachers and school employees will be conditioned to live in a competitive and individualistic. In the long term this will affect the mental and personality of students when they have grown, worked and moreover become public officials.

(2) Why shouldheadmaster give the task to someone according to their expertise and do the screening of prospective teachers and education personnel before running errands?

In an organization, including the organization of education, requires a clear organizational structure, especially Islamic school is a formal body definitely has a clear organizational structure. The organizational structure is a form of relationship duties and responsibilities as well as the competence of the person occupying a role in the organization. As already described in the previous chapter confirms that every person who worked and served at the school is for their accuracy among its membership people with the type of work assigned. An example is if the person concerned is a teacher educational background in math, the teacher primary task is to teach mathemathic and responsible for the retreat and advance of mathematics achievement at the Islamic school. Inconsistency in the competence is the beginning of the fall of the quality of education. Islamic school whose leadership is based on the Sunnah of the Prophet Muhammad is consistent with the concept of the right man on the right job. Leadership of the Prophet Muhammad would appreciate competence in carrying out tasks and jobs, especially tasks that provide services to the public. As has been narrated by Imam Bukhari, the Prophet Muhammad said:

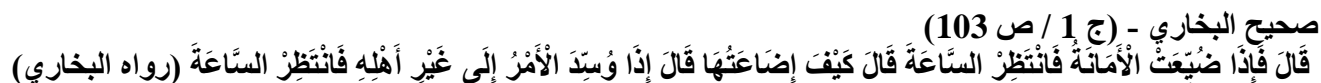
Meaning: The Prophet Muhammad said: when the mandate is wasted then wait destruction. Someone asked how wasted mandate? The Prophet said when an affair handed over to people who are not experts, so watch kehanncurannya (Nafi '2006: 103).

Far, 15 centuries ago in Saudi Arabia, before Indonesia formulate four competencies that must be owned by every teacher in Indonesia, the Prophet Muhammad in his leadership has given warning that if a person completes a task beyond his expertise, it is not a benefit and progress will obtained, but setbacks and even potentially lead to new problems more complicated. If it concerned experts and love to teach art, then the teacher must not teach history and so on. Prophet Muhammad Leadership upholds expertise specification and professionalism in the work. Competence in carrying out a very important task to achieve the goals and the quality of education that has aspired together. In fact, because thus the importance of implementing the concept of the right man on the right job, MA NU Banat specifically put these rules in a calligraphy boards that are attached to text vision and mission of the institution became the foundation philosophy of work for all citizens of substantial MA NU Banat in the discharge of their duties respective respectively, as shown below:

لو اخذ الناس مقا مهم لكان - قبل دخولهم الجنان في الجنان Meaning: Suppose man is willing to occupy their respective duties in his position, undoubtedly like already in heaven before entering heaven.

(3) Why does headmaster develop educators and education personnel?

Manage and develop and empower teachers and school employees actually need extra human resources management. One level is more difficult and complex than the human resource management in companies engaged in the management of the goods or services are only oriented to profit. Teacher human resource especially office employees plus. Because in addition to these teachers do activities as applicable to employees in general. Teachers must have the dedication, vision of humanity even noble task of God's command to continue and build human civilization. Islamic school which has commitment on educational quality are very concerned teachers and school employees. Either by giving the rights he deserved, welfare, reward and clarity of career forward as an ideal healthy by all employees or employees anywhere. 
(4) Why should qualityserve as a culture at the school?

There are differences between the leaders of educational institutions with leaders of other institutions such as the company's goods or services profit oriented. The heads of educational institutions are required to have a high sense of education and imaging institution led as a place for the purpose or practice and studying rather than for work purposes. That point of views are very important, so that all teachers, students and Islamic school citizens can focus and together creating a conducive learning environment for the realization of the vision of education. If necessary, establish educational institutions symbols or attributes of education to create a culture of achievement and moral designed in such a way in every corner of madrsah like in a classroom, office space, library, laboratory, pages and elsewhere at Islamic school. As described in the previous chapter that between form and attributes of education is to attach calligraphy taken from the text of the Qur'an, the hadith and the wise words of a philosopher or a cleric. The purpose of the attachment of such texts in addition to functioning art also and more importantly is to provide inspiration and motivation to learn is high.

One example of calligraphy text also reflects the leadership of headmaster who created the academic climate and the spirit of learning are:

ليس اليتيم الأي قد مات والاد اناليتيم يتيم العلم والادب

Meaning: not a so-called orphan is bereaved parents, but the orphans are the people who live there is no science and adab.

The text is very deep and philosophical meaning. In the view of educational leadership, knowledge and personality is a major, even the primacy of science and personality beyond possessions. To the extent that the child distress without parents still viewed as exhaustion are nothing when compared with children who still have two parents and full of treasures but poor science and personality.Quality culture in the organization of education is a situation where the entire school community, be it teachers, employees, students have a view that learning must produce quality plenary (total quality), the maximum and be competitive in this competitive era. School is not just enough to have a view about the quality. Schools must implement the views on the quality of education in all phases of activity (in put-proces-out put- and out Came). If the notion of quality has become a major major joints in the organizational culture of the school, all the learning activities will provide maximum results. Mutual relationship between school institutions and stakeholders awakened such a way that all components of education, both internal and external chime school, synergy and quality. This is what is expected by each institution.

\section{(5) Why must Islamic school headmasterbuild relationships with alumnus of Islamic school?}

Educational institutions can also be understood as coorperation (company) that manufacture or produce goods. Companies that produce goods or product is always listening to continuous and sustained by the customer. By listening closely perceptions about the advantages and disadvantages of the product, then the company will always make continuous improvements continuing to follow the will of the market. Similarly, educational institutions, including madrasas, should be oriented to alumnus as one way to control the quality of their graduates and membanguna quality desired by the user (user). Good Islamic school and getting support from the community, is a Islamic school institutions that have an accurate record of alumnus from year to year and has alumnusprograms of both the regular and irregulars. Islamic school with exceptional quality less attention and listen to the alumnus. Institutions such as madrasas also have complete and accurate data about the alumnus profiles. There are four things associated with the principles of total quality management, namely; (1) attention should be stressed to the process to continue - constantly echoed improvementquality, (2) the quality to be determined by the school services, (3) the achievements should be obtained through the understanding of vision rather than by coercion rules, (4) the school must produce students who has the knowledge, skills, attitudes arief wise, character, and have the emotional maturity (Edward Sallis: 2006: 221).

Typology of headmasterLeadership

Typology of MA NU Banat headmaster leadershipis set metavisioner educational leadership schoolsculture based sunnah of the Prophet Muhammad.

Why is type of headmaster leadershipin the form of Pesantren background?

Headmaster leadership in building relationships with educators, students and the community has a pattern of communication as relationships clerics and students, clerics and community (Ainurrafiq Dawam and Ahmad Ta'arifin: 2004)

Why is the type of headmaster leadership metavisioneroriented?

Leadership headmaster formulate a vision that goes beyond the ideals of human vision of an ideal world, but the madrassa vision oriented to the ideals of the afterlife as a form of true vision.

\section{Why is the type of headmasterleadership based Sunnah of the Prophet MuhammaadSAW?}

Prophet Muhammad as a prophet was exemplary and serve as the main reference profile leader who inspired leadership of headmaster. The Prophet Muhammad was a perfect figure, a leader in various fields of life. Muhammad Syafii Antonio (2007) explains that Prophet Muhammad leadership is holistic (reference to the leadership of all walks of life, accepted (accepted by faith as a prophet or not) and proven (typology leadership 
of the Prophet Muhammad is still and always relefan with all the space and time). Michael Hart (1978) Jewish descent profile put the Prophet Muhammad as leader of the world's most successful among the 100 world's most influential leaders. The Prophet Muhammad is a historical fact that most spectacular of leadership for the world community, in particular for Muslims

\section{Conclusion}

Discussion of findings from research on headmaster leadership abovecan be concluded, namely (1) morality and personality in educational institutions of NU Banat is very major. Even the headmaster moral standards in institutions is very high. In addition to be an clerics, learned in the science of religion also requires background formal education is relatively high and leadership experience in the wider community. (2) the vision of MA NU Banat Islamic schoolcontaining high ideals, quality orientation and with the hard work to make it happen. The dimensions of the ideal aspired to have possibilitydegrees realized with realistic parameters. Although this institution Sunni Islamic-oriented, but the agency is promoting nationalism. (3) the leadership of MA NU Banat in establishing communication with stakeholders through a variety of activities and forums which have structured and cultural forum. Discipline in upholding the discipline of students and teachers and staff adminisrasi with indiscriminately. MA NU Banat backed by religious leaders and scholars in Kudus. There are forums regularly both structurally and culturally keagaamaan that brought this institution dengana religious leaders in the community in order for cooperation to improve the quality of service is the better (4) MA NU Banat is Islamic school featured daughter. Leadership institute is oriented to high quality standards, excellent quality nature of academic and non-academic. Character and personality in this institution is a concrete manifestation dipertanggungjawaban quality graduates to the public (5) Typology of headmaster leadership is metavisionerleadership basedsunnah of the Prophet Muhammad set Pesantren.

\section{Bibliography}

[1]. Antonio, Muhammad Syafie. 2007. Muhammad SAW: The Super Leader Super Manager. Jakarta: Tazkia Multimedia \& ProLM Centre.

[2]. Basri, Hasan \& Tatang. 2015. Kepemimpinan Pendidikan, bandung: Pustaka Setia

[3]. Bush, Tony \& Coleman, Marianne. 2006b. Manajemen Strategis Kepemimpinan Pendidikan. Terjemhan Fahrurrozi. Yogyakarta: IRCiSoD.

[4]. Bass, Bernard M. 1981. Stogdills's Handbook of Leadership(A Survey of Theory and Research), Macmillan Publihsing, Canada, United State of America

[5]. Dawam, Ainurrafiq \& Ta'arifin, Ahmad. 2004. Manajemen Islamic school Berbasis Pesantren. Yogyakarta: Lista Fariska Putera.

[6]. Hasri, Salfen Hasri. 2004. Manajemen Pendidikan: Pendekatan Nilai dan Budaya Organisasi. Makasar: Yayasan Pendidikan Makasar.

[7]. Haikal, Muhammad Husain. 2006. Sejarah Hidup Muhammad. Terjemahan Ali Audah. Jakarta: Litera Antar nusa.

[8]. Hart, Michael. 1978. Seratus Tokoh Yang Paling Berpengaruh Dalam Sejarah. Terjemahan. H. Mahbub Djunaidi. Jakarta: Dunia Pustaka Jaya.

[9]. Hermino, Agustinus. 2014. Kepemimpinan pendidikan di Era Globalisasi, Yogyakarta: Pustaka pelajar.

[11]. Komariah, Aan \& Cepi Triana. 2005. Visionary Leadership (Menuju Sekolah Efektif). Jakarta: Bumi Aksara Moleong, Lexi J. 1998. Metodologi Penelitian Kualitatif. Bandung : Rosda Karya.

[12]. Mulyasa. 2002. Manajemen Berbasis Islamic school (Konsep, Strategi dan Implementasi). Bandung: Rosda Karya.

[13]. Multazam, Ahmad. 2013. Kepemimpinan Nabi Muhammad SAW. http://multazam-einstein.blogspot.co.id/2013/03/kepemimpinannabi-muhammad-saw.htm (18 Oktober 2016)

[14]. Mulyasa. 2011. Manajemen dan kepemimpinan Kepala Islamic school. Jakarta: Bumi AksaraMulyadi. 2010. Kepemimpinan kepala Islamic school Dalam Mengembangkan Budaya Mutu, Jakarta: Badan Litbang dan Diklat Kementerian Agama RI

[17]. Nafi', 2006. Software Maktabah Syamilah, http://www.almeshkat.net (diunduh 10 juli 2009)

[18]. Sallis, Edward. 2006, Total Quality Management in Education, Terj: Ahmad Al riyadi. Manajemen Mutu pendidikan, Ircisod: Yogyakarta.

[19]. Sugiyono. 2008. Metode Penelitian Pendidikan(Pendekatan Kuantitatif dan kualitatif, $R$ \& D). Bandung:Alfabeta.

[25]. Soekarno, Puji. R. 2008. Kinerja Kepala Sekolah dengan Indikator Emaslim.http://cindoprameswari.blogspot.co.id(diunduh 9 Oktober 2016).

[26]. Undang Undang Republik Indonesia Nomor 20. 2003. tentang Sistem Pendidikan Nasional. 2003.http://www.hukum.unsrat.ac.id. pdf (diunduh Oktober 2013)

[27]. Peraturan pemerintah Republik Indonesia Nomor 19. 2005. tentangStandar Nasional pendidikan.pdf. http://www. sindikker. ristekdikti.go.id. (diunduh september 2016

[28]. Peraturan Pemerintah Nomor32. 2013 tentang perubahan peraturan pemerintah nomor 19 tahun 2005. Pdf http://www. kelembagaan.ristekdikti.go.id. (diunduh September 2016)

[29]. Peraturan Pemerintah Nomor 19.2007 tentang standar Pengelolaan Pendidikan.pdf. http://www.sdm.data.kemendikbud.go.id. (diunduh September 2016)Wibowo, Agus, 2015. Pendidikan kaarakter, strategi membangun karakter bangsa berperadaban, Yogyakarta: Pustaka Pelajar

[32]. Wahjosumidjo. 2003b. Kepemimpinan Kepala Islamic school. Jakarta: Raja Grafindo Persada. 